\title{
The Influence of Ḥāfiẓ on Muḥammad Taqī Bahār
}

\author{
Bahman Solati \\ Department of Near Eastern Studies, University of California Berkeley, United States \\ E-mail: bahmansolati@berkeley.edu
}

Doi:10.7575/aiac.alls.v.7n.3p.260

Received: 17/02/2016

URL: http://dx.doi.org/10.7575/aiac.alls.v.7n.3p.260

Accepted: 13/04/2016

\begin{abstract}
Looking through the eyes of Persian culture, we see that man is not all noetic; he is not driven by intellect or consistent in his use of reason. On the contrary, he is most moved by emotion. A perfect example: Persian philosophy is most commonly uttered in both poetry and prose. This is, I believe, where the brilliance of Persians rests, in the beauty of its language and the expression of its culture. The endurance of Iranian literature and language over two and a half millennia is remarkable and thus deserving of both thorough research and an in-depth study. Here, I attempt to demonstrate the influence of Hâfiz, one of the greatest classical poets of Persia who ever lived, on the thoughts, poetic language, and philosophy of the gifted nineteenth-century Persian poet Muhammad Taqī Bahār, otherwise known as Malik al-Shu'arāa. I will accomplish this feat through close readings of the parts of Haafiz's poems and juxtapose them with Bahār's poems. My contention here, is to demonstrate any direct or indirect influence Ḥāfiz had on Bahār, and to also measure the extent of Ḥāfiz's reception during Bahār's period. With some modifications, the translations of Hiāfiz’s's ghazals used herein follow those of Peter Avery, while other translations throughout the book are my own, unless otherwise stated.
\end{abstract}

Keywords: Persian literature, languages, Persian contemporary and classical poetry, Hafiz, Styles and manners

\section{Introduction}

Observing society through the filter of Persian culture we see that human beings are not motivated by intelligence or consistent in their use of reason. On the contrary, they are most moved by emotion; as Hâfiz puts it, "One cannot love and be wise." Persian philosophy, which recognizes this ambiguity, is most frequently expressed in both poetry and prose. As Ḥāfiz also wrote,

$$
\text { كه شيخ مذهب ما عاقلى كنه دانست }
$$$$
\text { وراى طاعت ديو انعَان زما مطلب }
$$

(Ḥāfiz, Dìvān 1362/1984, 1: 48, v. 4)

Seek not from us anything within the boundaries of sanity,

For the Master of our order knew rationality to be sin.

Here, I attempt to demonstrate the influence of Hăfiz, one of the greatest classical poets of Persia, on the thought, poetic language, and philosophy of the gifted nineteenth-century Persian poet Muhammad Taqī Bahār, otherwise known as Malik al-Shu'arā. Through juxtaposed close readings of their poems, I will demonstrate the direct and indirect influence of Ḥāfiz on Bahār, and measure the extent of Ḥăfiz̧'s influence during Bahār's period generally.

Bahār believed that Fatḥ- 'Alī Shāh's reign (1797-1834) — also known as the Qājār period —was a brilliant time for poetry, a view in striking contrast to that of many scholars, who hold that the poetry of this period was essentially useless (Bahār 1351/1932, 1: 49). Although Bahār's view is barely supported by evidence, the poets of the Qājār period certainly performed a great service to neoclassical literature by reviving the words and thematic styles of the master poets of the past. For many critics today, however, the Qājār poets were unoriginal imitators. Poets such as Șabā, Furūghī Basțāmī, Șafĩ 'Alī Shāh, Sabzivārī, and many others continually manifest the influence of classical poets like Rumi, Sa'dī, and Hāfiz. Their attempts to emulate this remarkable poetry led to a revival of neoclassical literature that continues to this day.

I am not fully convinced that the negative views held by numerous critics of the poets of this period are fair and just. By reviving appreciation of the works of masters such as Firdawsī, Rumi, Sa dī, and Hâfiz, the neoclassical movement performed a great service. In what follows, I will examine the work of Bahār, a writer of the late Qājār and early Pahlavi period whose literary criticism is of great significance.

\section{A Summary of Literary Progress in Iran (1908-78)}

Early in the Constitutional Revolution, around 1284/1905, many political assemblies were formed. While some were comprised of true activists with nationalistic ideas and honorable intentions, the leaders of other movements sought only to protect their own interests and not the good of the state. One of the latter assemblies was Anjuman-i Himmat (The 
Society of Aspiration) (Bahār 2006, 1:190). This group was formed by fundamentalists in Mashhad, led by an illiterate man known as 'Alī Akbar Hasanī. Bahār denounced their views and methods in the following couplet:

Bahār

(Bahār 2006, 1: 190)

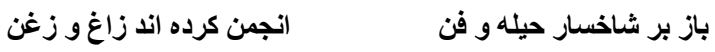

Once again, on the branches of fraud and sham,

Assembled are the black-winged Ravens and Crows!

During the half century between $1299 / 1920$ and $1357 / 1978$, many different governments came to power in Iran, almost one each year (Subhān̄i 1386/2007, 633). This volatility and the rise and fall of so many prime ministers were caused by the tentative foreign policies of the court and the varying views of the people. Riḍa Shāh at first focused on national progress, bringing to the state a degree of security and stability; (Abrahamian, 149; Keddie and Richard, 88-89; Mackey, 1998, 158-59). but this came at a price. During his reign, the metropolitan police censored the press (Subhānī, 633). Only progovernment journals and magazines could circulate. Some newspaper editors of the time experienced extreme hardship. Farrukhī Yazdī (d. 1318/1939), a political poet and writer, was among those confined and killed (Dihkhudā 1373/1994, 10:15039, s.v. “Farrukh"̄”).

In $1311 / 1905$, probably as a result of the sociopolitical chaos of the early Constitutional Revolution, Iranian literature began to transform itself. The Persian poetry and prose of four writers of the pre-and post-constitutional movement displayed a greater willingness to use straightforward contemporary language and a relative discomfort with classical style. The first of these writers was Zayn al- 'Ābidin Marāgha'̄̄, whose Sìyahat-nāma-yi Ibrāhīm Bayk (The Travel Log of Ibrāhìm Bayk) introduced simplicity in prose. The second was Țālibuf, whose educational stories also demonstrated an innovative simplicity (Maliki Iran Nameh, 18: 1 2006; 67). The third was Dihkhudā, famous for his witticisms and his series of articles titled Charand u parand (Claptrap). The fourth was Jamālzāda, renowned for the short stories and proverbs collected in his Yakī būd yakī nabūd (Once upon a Tìme) (Subḥānī 1386/2007, 634).

These authors sought to outdo each other in the production of new concepts and meaning. Sometimes they fell short and resorted to Western expressions (Talattof, 2000, 20). In 1288/1909 alone, ninety-nine new journals were published (Sipanlu 1366/1988, introduction). In addition, these journals often published the works of 'Ārif, 'Ishqī, and Yazdī, poets of eloquence and clarity. These journals had an enormous influence on the common writing style of the people of Iran (Sipanlu 1381/2002, introduction).

These scholars helped transform the Persian language, making it more accessible to everyday Iranians and encouraging them to read, previously an activity of the learned minority. As exchange with the West increased and the population became more familiar with European countries and customs, the school of romanticism began to flourish in Iran. Translations of Western articles and short stories were disseminated. Western writings gained admiration and replaced the morality plays of the Qājār period (Āryānpūr 2:302-04). After Jamālzāda's short stories, the stories of Șādiq Hidāyat slowly found their way into the literary ambiance of early Pahlavi Iran.

During this period, poets focused on nationalistic poetry; among poets such as Bahār, 'Ārif Qazvīnī, Mīrzāda `Ishqī (d. 1303/1924), and Adib Nayshābūrī, nationalism became the predominant theme (Āryānpūr, 2: 20). However, some poets of this period still followed the style of the old masters, such as Sa dī and Hāfizạ, and avoided politics. Parvin I'tișāmī, a celebrated poetess of the early Pahlavi period, primarily composed qașida, qaț 'a, and mathnavī; her chefs-d'oeuvre can be found in her couplets, and throughout her poetry one senses a certain mysticism (Parvin I'tișāmī 1382/2003, 13-18).

After the Constitutional Revolution, poetry thus moved in two different directions: classical poetry and new poetry. Classical poetry followed the styles of the old masters and was bound by their rules of prosody and meter. New poetry was not limited in prosody and meter; its object was profundity of meaning, not rhyme (Subhān̄ī, 634). Gradually, new writers confronted the traditionalists in a more organized way. The traditionalists, indeed, already had their own societies-including Maktab-i Sa dī (Sa dī’s School) and Anjuman-i Niẓāmī (Niz̄āmī’s Society)—and published articles in journals such as Naw Bahār (New Spring) and Āzädistān (The Land of Freedom). The modernists formed similar official establishments, such as Dānishgāh (The Place of Knowledge), and informal groups such as Rab (The Four), headed by Șādiq Hidāyat (Talattof 2000, 21).

In general, the term Pārsīgiră ' $\bar{l}$ (Persianism) best defines the nature of the literary movement during this period. The program of the Persianists was to denounce the use of Arabic terms and terminologies, to improve the Persian language through poetry, to advocate a language closer to colloquial speech, to connect ancient Iran to the present, and to eliminate centuries of Islamic authority from the memory of the nation (Talattof, 25). In an interview with Homayoon Katouzian, a prominent Persian scholar at the University of Oxford, I raised this issue and he replied as follows:

This national sensitivity about Persianism began during the period of Rị̣ā Shāh's reign. Some elites and scholars established a literary society called Farhangistān [Place of Learning]; its role was to remove all Arabic words from the Persian language and replace them with similar words in Persian and then submit them to the Shāh; once approved, this would be officially recognized as a new vocabulary (Personal communication from Homayoon Katouzian 2009; Solati 2013, $110)$. 
Katouzian further stated that this became rather ludicrous when Sayyid Hasan Taqizāda, a renowned scholar and writer living in Berlin at the time, wrote an article criticizing Persianist language refinement. He appealed to the Shāh to reject it, arguing that Arabic had so thoroughly melded with Persian that efforts to remove Arabic influences would cause the very structure of the Persian language to collapse. Rị̣ā Shāh was infuriated by this commentary and Taqizāda, fearing for his life, did not return to Iran until Riḍa Shāh was exiled (Personal communication from Homayoon Katouzian 2009); (Solati 2013, 110).

\section{Bahār's Life and Work}

Muhammad Taqī Bahār, one of the greatest poets and writers of contemporary Persia, was born in the Sarshūr District of Mashhad on 6 November 1884 (Gulbun 1351/1972, 1:1). Bahār started his primary education when he was three years old under the direction of his father, Muḥammad Kāẓim Sabūrī. Muhammad Kāẓim was the poet laureate of the shrine in Mashhad and had the honorific title of Malik al-Shu'arā (King of Poets). In addition to his private education, Bahār joined one of the traditional schools, Maktab Khāna, in Mashhad. To improve his understanding of Persian and Arabic, he attended the classes of Adīb Nayshābūrī, an old-style poet and literary scholar who supported the Khurāsānī style of poetry, widespread during the early Islamic period, in the tradition of the Bāzgasht-i adabī (Neoclassical movement) (Cited in M. B. Loraine, J. Matīn̄i EIr, III: 476-479).

Many credible sources claim that Bahār learned the better part of the Qur'ān by heart at a very early age. Bahār himself claims that at seven he read Firdawsī's Shāh nāma (The Epic of Kings) and fully grasped the meaning of the poems (M. B. Loraine, J. Matīnī EIr, III: 476-479). When Bahār composed his first poem at the age of eight, he decided to choose a pen name in honor of Bahār Shirvān, a poet and close friend of his father's. Bahār began using his pen name shortly after Shirvān's death (Āryānpūr 2:123).

Bahār became fluent in Arabic and later learned to read, write, and speak French. Bahār's involvement in religious activities and preaching began shortly after his father passed away (Āryānpūr 2:123). He composed the following verse as part of a twelve-line elegy expressing his sadness at the death of his father:

Bahār

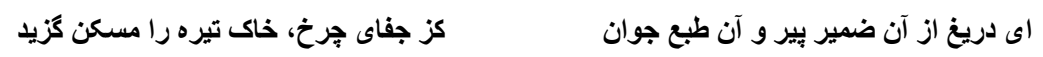

(Bahār, Dīvān 1: 45, Q 1, verse 5).

Alas, that young-natured-old-soul chose the dark earth,

Due to the cruelty of fate, as his abode!

After the death of his father when he was eighteen, Bahār began working as a local preacher and cleric. During this time he composed a long ode (Qașida) and sent it to Muzaffar al-Din Shāh, who was so impressed by this piece that he instantly selected Bahār as his poet laureate and by royal decree at the shrine of Imam Riḍa in Mashhad gave him the title of Malik al-Shu'arā (M. B. Loraine, J. Matīn̄̄ EIr, III: 476-479). In 1942 Bahār published his first book, Sabkshināsī yā tārīkh-i tattavur-i shi 'r-i Fārsī (Stylistics or the History of Transformation in Persian Prose). Published in three volumes, the work examined grammatical and literary changes in Iranian prose literature from the Achaemenid Dynasty (ca. 700 to $330 \mathrm{BCE}$ ) to the early twentieth century. Bahār's primary purpose in producing these volumes was to enable students to identify various styles of Persian poetry. These volumes are one of the earliest instances of contemporary Iranian literary scholarship. Bahār himself recognized this gap in Persian literature and called the subject a "new science" (Bahār 1373/1994, 32).

Sabkshināsī was based on a series of discussions Bahār led at a literary society in 1930 and 1931. The study of prose literature had been abandoned in schools of all levels during this period, and the lack of an organized system of instruction became quite apparent. Later, in the journal Armaghān, edited versions of these speeches were published for one year, under the title "Literary Return" ("Bāzgasht-i adab̄̄”). Riḍāāâda Shafaq soon published a chapter based on Bahār's talks in The History of Iranian Literature for High School. The articles ignited a debate about Sabkshināsī among scholars and young people who knew little of the subject. Nevertheless, the discussion did not leave the boundaries of poetry, encouraging Bahār's in-depth examination of prose literature (Bahār 27).

Shortly after 1933, he spent a year teaching the history of Persian literature at the Dār al-Mu'allimin-i 'Ālī, an institution for tutors of secondary education (it was later named Dānishsarā-yi Ālī), and during this period he edited a few classical manuscripts, including Tārikh-i Sistān and Tārikh-i Tabarī. Bahār also published articles on "The Change of the Persian Language" in the journal Bākhtr (The West). In addition, he was asked to lecture at the University of Tehran. Sabkshināsī was subtitled The History of Transformation in Persian Poetry and Prose (Bahār, 28). Bahār's contribution to Persian poetry is immense. His Dīvān includes more than 40,000 couplets, including rubā' $\bar{l}$, ghazal, qașida, qaț $a$, and mathnavī (Khalkhālī 1331/1953, 28). Throughout his life, Bahār wrote poems in all the classical styles; he occasionally tried his hand at verse forms from other countries, but near the end of his life he foreswore new forms of verse and reverted exclusively to the old style of poetry, following the classical masters. His themes, and often his phrasing, however, are clearly contemporary (M. B. Loraine, J. Matīn̄i EIr, III: 476-479). Bahār died in Tehran in $1330 / 1952$. 


\section{Terms and Phrases Employed in Hạafiz’s Poetry}

According to Muhammad 'Alī Nudūshan, an Iranian contemporary scholar, the mystery of Hāfiz's poetry does not rest simply in his language; the rudiments of his poetry, idiom, music, expression, and meaning mix to form a living entity. Therefore, the efforts of commentators and critics to examine and interpret his poetry generally fail to grasp the heart of his poetic language (Nudūshan Iran Nameh, 6: 4 [Summer 1988], 521).

Hāfiz
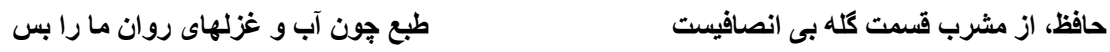

(Hāfiz, Dīvān 1362/1984, 1: 262, v. 8).

It is unjust, Hāfiz, to judge your fate harshly:

The flow of verses from your spring-like nature is quite enough.

In this section, I review terms and phrases that Hăfiz used in his poetry and briefly summarize his poetic style and the devices used in his poetic language. This will enable us to better understand his influence on Muhammad Taqī Bahār. Hāfiz mostly composed his poems in forms of ghazal (lyric style). The theme of the ghazal is mostly love, be it worldly or divine. A few lyrics and odes convey political messages as well as advice on morality. To the untrained reader, however, the poems may appear to lack rational development. They seem to be tied together mainly by the rhyme, and Johann Wolfgang von Goethe was indeed correct remarking that this form, instead of accumulating the spirit, scatters it as the rhyme points to entirely different and apparently unrelated things. This results in the poems' appearance of prescribed end rhymes; to engender something delicate in this style, great poetic skill is required (Schimmel 1992, 22).

In some cases, for example in a few of Rumi's poems, a ghazal appears as a reasonably closed unit, simply carried by meter and rhyme. Even the most painful images and the poet's most agonized sighs are expressed with such delicate skill that they do not upset readers but rather stimulate in them a kindred feeling of gloom. The ghazal articulates the never-altering human sentiments of love, sorrow, desire, courage, and misery-the delight of spring, an autumnal melancholy - with traditional images in which the experience of millions of human beings is refined to a sweet-scented spirit (Schimmel 1992, 22). Hâfiz in turn, drives the ghazal to great heights and delivers it to the reader with delicately and delightfully composed messages of counsel, direction, and wisdom.

Hāfiz understood his poetic standing and his ability, and he referred to his own achievement in many verses. The mastery and skill of Hāfiz's poetry make the works of other poets — whether his contemporaries or modern-day poets pale by comparison. Poetry is the prevailing branch of Iranian literature, Persian verse being recognized as superior to Persian prose. Hāfiz's style of poetry results both from his poetic persona and from other factors we will discuss later "Sincerity is a function of style, involving a relation between the artist and the public; it has to do with the presentation of a self-appropriate to the kind of verse being written, to the genre, not with the personality of the poet. . . In ancient literature it is the personality expressed in the poem, not the personality of the historical poet, that signifies." (Elliot 1982, 43-45). Many aspects of Hāfiz̧’s ghazals seem to have originated with earlier poets. By Hāfiz’s time the ghazal already had a long history, going back almost two centuries. It would be difficult to point to any single element of Hâfiz's ghazals, either formal or thematic, that is not visible in the works of his predecessors (Bruijn EIr, 11: 400-474).

In order to assess Hâfiz's personal contribution to the development of the ghazal, we must take into account his debt to his predecessors - and even to his contemporaries who cultivated the same genre. We can only accurately assess his originality after examining all possible influences on his work (Bruijn EIr, 11: 400-474). In this regard, Muhammad Reza Shafī’̄ Kadkan̄̄, a current-day scholar, poet, critic, and author, believes that the clarity and fluency of Hāfiz's verse results from his vast knowledge of the Persian language and the poems of both his predecessors and contemporaries.

Kadkanī further argues that Hāfiz comprehended the wealth of the culture embedded in the Persian language itself (Kadkan̄i 1380/2002, 154-57). Hậfiz's style of poetry was derived from the 'Irāqī style and some aspects of the Khurāsānī style. However, some scholars today believe that a style of poetry is merely a vehicle the poet uses to deliver his message (Mahjūb 1363, 40-41). Muhammad Ja far Maḥjūb, a prominent current-day Iranian scholar, was of the opinion that poets compose poetry according to their own sociopolitical perspective; he viewed the environment in which the poet lives as having the greatest impact on the poet's style of delivering his or her message. Another contemporary scholar, Sirus Shamīsā, views Hāfiz's ghazals as an echo of the 'Irāqī style. He also asserts that this style of poetry should have ceased to exist in the fourteenth century but that the socioeconomic conditions of the fifteenth century kept new master poets and new styles from emerging to replace it. In the fourteenth century, the attack on Persia by the Turkic conqueror Tīmūr (Tamerlane) brought about a cultural and social decline. In literature, this decline continued into the first half of the fifteenth century, sometimes known as the Age of Shāhrukh (the fourth son of Tīmūr, r. 807-850/1400-1443) (Losensky 1998, 50).

During Shahrukh's age, the poetry market was buoyant; both literature and art were sponsored and cultivated. However, after Shahrukh's death, this attention to the arts faded away and was never recovered. This decline was a result of the problems the state faced, particularly the poor economic and sociopolitical situation. There was neither social nor economic security, and high rates of unemployment and crime existed (Losensky 1998, 50). 
Since literary works of high quality could not thrive, the customary creative practice was imitation of the works of old masters (Yarshater 1334/1956, 79-81). Ehsan Yarshater asserts that during the latter half of the fifteenth century, many poets imitated master poets such as $\mathrm{Sa}{ }^{\mathrm{d}} \overline{\mathrm{i}}$ and Hāfiz. One of the last great poets of this period was Jāmī, who also followed the 'Irāqī style. He flourished shortly before the Indian style emerged (Shamīsā, 256-57).

Shamīsā believes Hāfiẓ’s genius is partly a result of this Sufi element in his ‘Irāqī-style poetry (Shamīsā 1383/2005, 98). Hāfiz’'s status and importance as a poet does not spring solely from his poetic skills; it is partially attributable to his forthright challenge to duplicity and dishonesty.

According to Abu'l Khayr, deception is a disease destroying all societies from within - in particular, the Eastern civilizations. Unless it is opposed and stopped, in Abu'l Khayr's view, the damage will be irreversible. Abu'l Khayr counseled cherishing the moment—vaqt. This is a term largely used by the Sufis. It refers to the time a Sufi spends in solitude - in a state of meditation, time has no significance and the Sufi is in neither the past, the present, nor the future. This is considered the moment in which the Sufi experiences life in its true essence (Abu'1 Khayr, ed. Kadkanī, 1: 93). The following verse illustrates Hăfiz’s philosophical parallelism to the vaqt:

Hạfiz

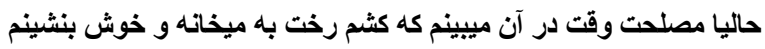

(Ḥāfiz, Dìvān 1320/1941; 1381/2003, g 355, v. 1).

The only wise course for me at this moment is

To move my possessions into the tavern and there

Cheerfully settle down.

Haafiz is exclusively known for his ghazals, lyric poems of approximately seven to nine lines. His poems in other categories have barely earned a place in the general consciousness, with the possible exception of his $S \bar{a} q \bar{\imath}-n \bar{a} m a$, a poem in couplet form about wine and drinking, frequently harmonic in a specific style of traditional Persian music. His ghazals comprise mostly independent lines, tied together by a single meter, a single rhyme, and sometimes a radif - a word or phrase repeated at the end of each line.

The first line, matla', usually sets the mood of each ghazal, but this is rarely followed through in all the lines. The feeling and emotion in other lines is determined by numerous characteristics: the overall mood or inspiration involved in composing the ghazal; the requirements of the rhyme and the radif; the poet's undulating elegance; and perhaps a reflection of the harmonious mode or melody envisioned for each line. Hāfiz appears to have written his ghazals to be sung as well as recited. Unequal and randomly chosen as the contents of Hāfizian ghazals seem, they all fit into a magnificent thematic structure, slowly established as the poem progresses, from which the poet may choose the subjects of his choice and suggest his own distinctions among them.

Among the figures offered or confirmed by Hāfiz are ones common in Persian lyrics, such as those of "the beloved," "the poet-lover," "the giver of advice against love," "the guardian of the beloved turned rival," "the Sāqī, or youth, who serves wine in drinking sessions," as well as such themes as "the adoring lover," "the indifference of the beloved," "the symbolic love of the nightingale for the rose," and "the devotion of the moth to the candle flame" (Yarshater EIr, 11: 461-65). Hāfiz employs various poetic terms for hypocrisy and deception. He makes frequent attempts to repent for insincere asceticism:

Hāāiz
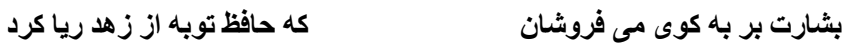

(Hāfiz, Dìvān 1362/1984, 2: 126, v. 10).

Take the good news to the vintners' lane

That Ḥāfiz has repented of false devotion.

Hāfiz informs the reader of his verses about Sufi spiritualism, with its ciphers of fake devotion, also known as dalq-i riya ' ' $\bar{\imath}$ (the cloak of deceit) (Lewis EIr, 11: 483-91).

Hāfiz

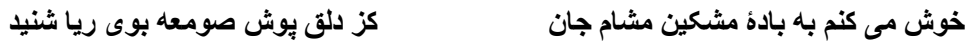

(Ḥāfiz, Dīvān 1362/1984, 2: g 238, v. 5).

With the scent of wine, I fill my soul with joy,

For, from the cloak-wearer of the monastery, I sniffed the odor of hypocrisy.

According to Hāfiz, extreme hypocrisy puts the whole basis of religion on unstable ground:

Hāfiz

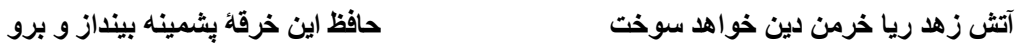


The fire of a deceitful cleric will eventually consume the harvest of

Faith; throw away this woolen robe, Hāfiz, and be on your way.

Through the dynamic voice and images of his ghazals, we can often observe the poet accusing himself of hypocrisy and deceit:

Hāfiz

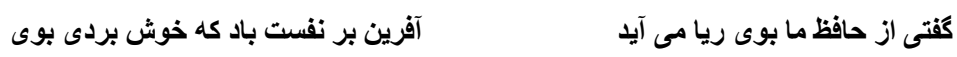

(Hāfiz, Dīvān 1362/1984, 2: g 476, v. 8).

You said: "Our Hāâfiz smells of hypocrisy."

Bravo on your breath, you so well got the wind of it (Avery 576, $g$ 476).

Hāfiz hopes to escape all contact with "hypocrites" such as the muhtasib, who is deeply involved with his insincere show of piety. Indeed, very few people are free of deceit; if the nightingale sings motivated by deep friendship or $a z$ sar-i sidq (through sincerity), the general public displays impudent hypocrisy or riyā-i khalq (hypocrisy of the nation):

Hāfiz

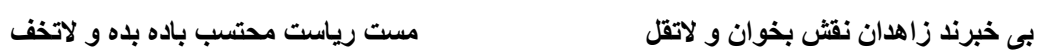

(Ḥāfiz, Dìvān 1362/1984, 2: g 290, v. 7).

Phony ascetics are ignorant-

Sing the song and tell it not.

The Sheriff "muhtasib" is elated with hypocrisy.

Give wine and fear not.

Hāfiz

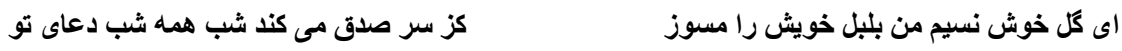

(Ḥāfị, Dìvān 1362/1984, 2: g 430, v. 2).

O my freshly scented rose, do not scorch your nightingale

Who in pure sincerity nightly, the whole night,

Remains lingering and emotionally commits to you.

Ḥāfiz
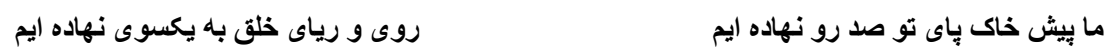

(Ḥāfiz, Dìvān 1362/1984, 2: $g$ 357, v. 1).

A hundred times have we bowed and laid

Our face in the dust beneath your foot

While putting aside the hypocrisy of people.

Duplicity is interpreted as a concept opposite the veracity or "truth of drinking wine." In fact, wine washes away the stains of pretense:

Hāfiz

$$
\text { مكر ز مستى زهد ريا به هوش آمد }
$$

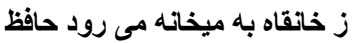

(Ḥāfiz, Dìvān 1362/1984, 2: g 171, v. 8).

Hāfiz is leaving the Sufi temples for the tavern;

Perhaps he has come to his senses from the inebriation

Of the phony clergy.

Ḥāfiz

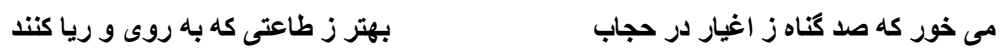

(Hāāiz, Dìvān 1362/1984, 2: g 191, v. 6). 
Drink wine, for a hundred sins committed behind the veils

Prevail over insincere and slavish devotion.

Hāfiz

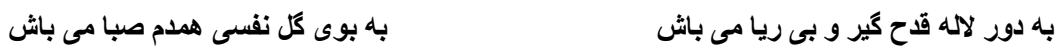

(Hāfiz, Dīvān 1362/1984, 2: g 269, v. 1).

In the season of the tulip, take the cup and be sincere

With the attar of the rose, for a moment be a confidant of the breeze.

Hāfiz

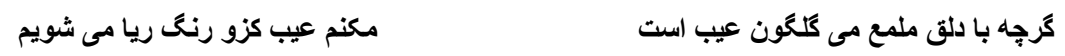

(Hāfiz, Dìvān 1362/1984, 2: g 373, v. 5).

Although the multicolored cassock does not go with the color of wine,

Do not fault me, for I wash away the stains of hypocrisy with it.

However, closing maykhāna (the taverns) will lay the grounds for the doors of the house of hypocrisy to open - that of riyā and tazwir (Lewis, EIr, 11: 483-91).

Ḥāfiz

$$
\text { در ميخانه ببستند خدايا مبِند }
$$

(Ḥāfiz, Dìvān 1362/1984, 2: g 197, v. 6).

They have closed the tavern door. O God, consent not,

For they will be opening the door of the house of fraud and sham.

A term used frequently throughout the $D \bar{l} v \bar{a} n$ is $s \bar{a} l \bar{u} s$, employed as an adjective for khirqa (robe) or other type of garment that broadcasts the Sufi's divine state; it always means counterfeit or pretense. It also conveys deceptiveness and falsity in regard to moral deeds - adhering to moral principles - the hypocritical claptrap of the cleric, or just general piety:

Hāfiz

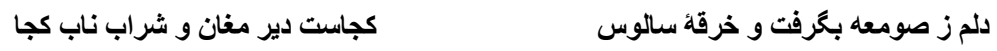

(Hāfiz, Dīvān 1362/1984, 2: g 2, v. 3).

My heart withered away because of the convent and the cloak of hypocrisy:

Where is the Magian Temple, where the rare wine?

Ḥāfiz

وين نقش زرق را خط بطلان به سر كشيم

صوفى بيا كله جامة سالوس بركثيم

Ḥāfiz, Dìvān 1362/1984, 2: g 368, v. 1).

Come, Sufi, let us take off the robe of hypocrisy

And repel this image of fraud.

Hạāiz

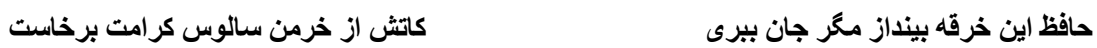

(Ḥāfiz, Dīvān 1362/1984, 2: g 28, v. 7).

Hāfiz, leave behind this tattered gown; perhaps you will save

Your soul, for from the heaping harvest of sham a fire has sparked.

Ḥāfiz

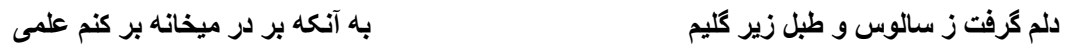

(Hāfiz, Dīvān 1362/1984, 2: g 462, v. 5). 
From hypocrisy and acts of mendacity, my heart withered away

- better to raise a flag of higher standards at the tavern's door.

Hāfiz

$$
\text { كردن سالوس و تقوا بثكنى }
$$

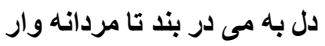

(Ḥāfiz, Dīvān 1362/1984, 2: g 469, v. 2).

Bestow the heart to wine so that like a man

You may snap the neck of piety and deceit.

Hāfiz

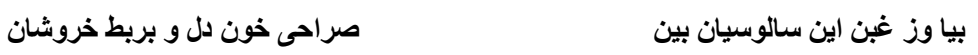

(Ḥāfiz, Dìvān 1362/1984, 2: g 379, v. 4).

Come and from these cheating phonies, perceive,

The heart of a goblet filled with bloodlike wine

And hear the lament of the lute.

Throughout his poems, the poet appears to be telling us that all ascetics and Sufis of his time concealed the truth to some degree, and Hâfiz is far too clever to be duped. Although wine-drinking and love-making are considered sinful, the fundamental sin is misinterpreting the Qur'ān to endorse deceitful piety and involve oneself in wrongful deeds. Often we encounter instances where Hâfiz does not exclude himself; he is a sinner. But by declaring his own involvement with sinning and misdeeds, he sends the message of sincerity and communicates to his admirers lessons in honesty and morality:

Hāfiz

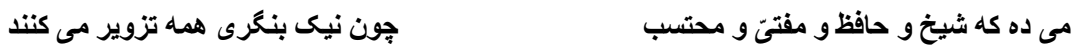

(Ḥāfiz, Dìvān 1362/1984, 2: g 195, v. 9).

Bring wine! For clerics, Hāfiz, erudite-learned, and religious emissaries,

When you look closely, are all filled with lies and deceit.

Hāfiz

$$
\text { من نه آنم كه دكر كوش به تزوير كنم }
$$

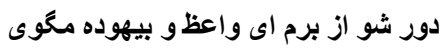

(Ḥāfiz, Dìvān 1362/1984, 2: g 339, v. 7).

Go about your own business, $\mathrm{O}$ preacher, end this muttering nonsense-

I am not the one to lend an ear to lies and deceit again.

Ḥāfiz

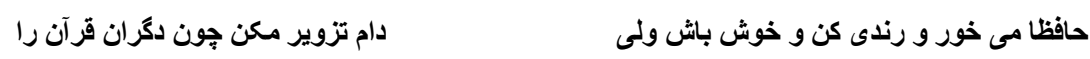

(Hāfiz, Dìvān 1362/1984, 2: g 9, v. 10).

Ḥāfiz, drink wine, be roguish and elated, but

Do not, as others do, use the Qur'ān to lay a net of deceit.

Similar to sālus, zarq repeatedly modifies the nouns jāma and dalq (or clothing). Zarq can be the dishonesty of a design or naqsh (a pattern), of a cloak that conceals a wine carafe, or the social rank suggested by a uniform that must be discolored with wine to prevent vanity. Often wine is advised as the cure for such dishonesty, which may be equated with dust that must be washed away by wine. Hāfiz pledges not to forgive dishonesty (Mu'īn, 1389/2011, 476). Similarly, he uses the term qalb u daghal, a kind of counterfeit sham of sanctity to fool the general public, or even God. The zuhd-furūsh is one who seeks to sell his piety through impudent hypocrisy, which is, unfortunately, often the inspiration to help others.

Ḥāiziz

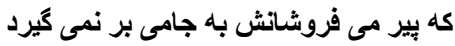

من اين دلق ملمع را بخوا هم سوختن روزى 
(Ḥāfiz, Dìvān 1362/1984, 2: g 145, v. 4).

One day I shall burn this stained, patched-frock

That the Elder of the vintners won't exchange for a cup of wine.

Ḥāfiz

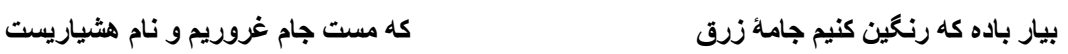

(Hāāiz, Dīvān 1362/1984, 2: g 67, v. 3).

Fetch wine for us to color the gown of hypocrites:

We are elated with pride, yet sobriety is the name of our ecstasy.

Hạfiz

$$
\text { كو در حضور بيز من اين ماجرا بكو }
$$

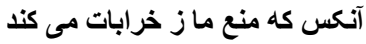

(Hāfiz, Dīvān 1362/1984, 2: g 407, v. 10).

Tell he who is forbidding us the tavern,

To repeat in my Elder's presence this refusal!

Hāfiz

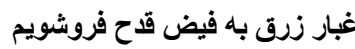

بيار مى كه به فتوى حافظ از دل بِاى

(Hāfiz, Dìvān 1362/1984, 2: g 373, v. 9).

Bring wine because, by the declaration of Haafiz from an untainted heart,

With a goblet of wine, the filth of deception we shall launder.

Hạăiz

$$
\text { بهتر از زهد فروشى كه درو روى و رياست }
$$

(Ḥāfiz, Dìvān 1362/1984, 2: g 25, v. 4).

A wine-drinker in whom there's neither deviousness nor hypocrisy

Is better than the abstinent clergy in whom there are both.

Although zarq does not normally explicitly signify concealment and sham, Hāfiz consistently uses it to modify tawba (repentance) in contexts of insincerity. "Repentance" suggests renouncing the evil ways of drink and other unlawful desires, and a sensible mind finds this hard to envisage (Lewis EIr, 11: 483-91).

Hāfiz
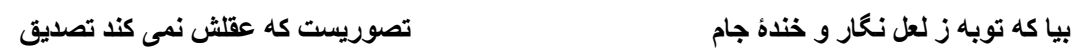

(Ḥāfiz, Dìvān 1362/1984, 2: g 292, v. 5).

Come, because repentance of the idol's ruby-lips

And the laughter of the bowl of wine is an illusion that reason does not confirm (Avery 364, $g$ 292).

\section{5. Ḥāfiz and Bahār}

Many believe that Hāfiz was a political poet, or at least that some political expressions can be detected in his poetry. Throughout his Divān, we encounter sharp language used for kings and rulers; these can be interpreted as statements of the poet's disapproval of monarchs. Some scholars also believe that he was a court poet and thus rendered literary services to kings and rulers in return for income. However, this claim seems dubious and has very little support. Many instances in his $D \bar{\imath} v \bar{a} n$ indicate his disassociation from kings and sovereigns.

Hạfiz

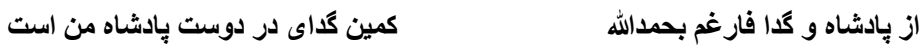

(Hāfiz, Dìvān 1362/1984, 1: g 54, v. 3).

I am free of both king and beggar, God be praised!

The least beggar at the door of the Friend is my king (Avery 91, $g$ 54). 
Ḥāfiz

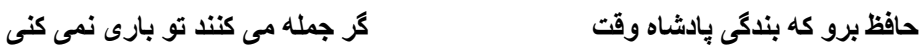

(Hāiäiz, Dìvān 1362/1984, 1320/1941, g 482, v. 8).

Go, Hāfiz, although all are performing service to the king,

You do not.

Ḥāfiz

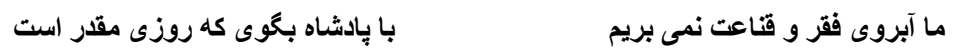

(Hāfiz, Dìvān 1362/1984, 1: g 4, v. 10).

We do not betray the dignity of penury and contentment;

let the king know that our daily sustenance is preordained.

In this regard, I would draw attention to the following comment by Leonard Lewisohn, with whom I discussed the issue of Hāfiz’s's political stance.

Hâfiz was an anti-Monarch poet too. In some instances he harshly criticizes the king. Of course, this goes back to the malamatī (Blameworthy) Sufi order he followed and believed that one should not bow and pay homage to social authorities, kings in particular. Therefore, those who believe or claim that Hāfiz was a court poet are very much mistaken. If he was a court poet, he would not have expressed his views, sharply spoken, towards kings and rulers. If he did, he would have probably been afraid of his income "from the court" being cut. We would be right to some extent to refer to Hāfiz as a political poet, but not one like Shāmlū or Bahār. The political side of Ḥāfiz̧'s poetry is one layer out of many . . . . Besides, he does not directly discuss politics, his words of wisdom make references to the unsatisfactory political situation that existed during his time. There are, however, some political angles and dimensions visible in his poems (Personal communication from Leonard Lewisohn, Exeter, February 2014).

Bahār, in contrast, believed in simple writing, and demonstrated this in his poetry. He was a strong political poet and, like Hâfiz, opposed the absolute power of kings and advocated democracy for all. In many of his poems he fearlessly insults the kings of his time. Bahār composed the following verse about the incompetence of Nāṣir al-Din Shāh Qājār in $1290 / 1911$.

Bahār
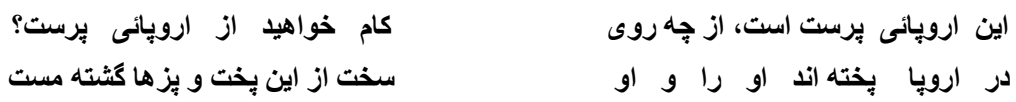

(Bahār, Dīvān, 1: 245).

He is a European-worshiper, why do you desire

anything of a European-worshiper?

They have ripened him in Europe-

and he has become intoxicated with all of this ripening.

In 1295/1916, Bahār composed the following to urge Ahmmad Shāh to care for his people:

Bahār
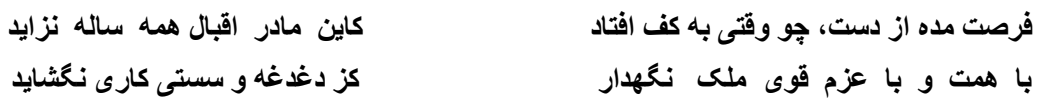

(Bahār, Dīvān, 1: 315).

Seize the moment, once opportunity knocks,

For the mother of fortune shall not give birth every year.

Manage the kingdom with great determination and gallantry,

State affairs cannot be resolved through fear and weakness. 
By the following year, his criticism of Ahmad Shāh had turned harsh:

Bahār

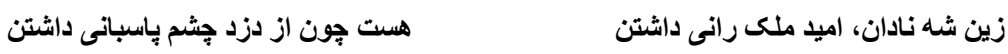

(Bahār, Dìvān, 1: 316).

To expect a state to come from this ignorant king

Is like expecting a thief to act as policeman.

To compare the two poets' words of wisdom on the ways kings did and should rule, let us juxtapose the following verse from Hāfiz. It offers advice to Tīmūr circa 790/1390, shortly before the poet's death (Ghanī 1344/1966, 1: 35).

Ḥāfiz

$$
\text { عنان كثياه رو ایى بادشاه كثور حسن }
$$

(Hāfiz, Dīvān 1362/1984, 1: g 76, v. 7).

O King of the land of beauty, go with your horse reined in,

For on no highway is there not a seeker of justice (Avery 116, $g$ 76).

The following examples demonstrate different styles in which Bahār and Hāfiz complain about the political situation of their times. One can clearly feel the reigning discomfort in their utterances. While their styles are far apart, the message is the same. This probably reflects the different political eras to which they adapted themselves. The verses given by Hāfiz are clear evidence of Lewisohn's statement above: "He does not directly discuss politics, his words of wisdom make references to the unsatisfactory political situation that existed during his time." Bahār's elegy offering advice to Rị̣ā Shāh in 1307/1928 is merely related to greed and obstinacy; while Hāfiẓ’s advice is not aimed at a particular figure and is milder in tone and wiser in context.

Bahār

$$
\text { تو دكر سباشد ز لجاج و ز طمع بلتر كار }
$$$$
\text { بادشاها ز لجاج و ز طمع دست بردار }
$$

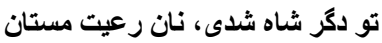

(Bahār, Dìvān, 1: 437).

O King, give up obstinacy and greed,

For there is nothing nastier than them both.

You are the king now, do not take the peasants' bread-

You are the king now, do not squeeze the hungry.

Or

Bahār
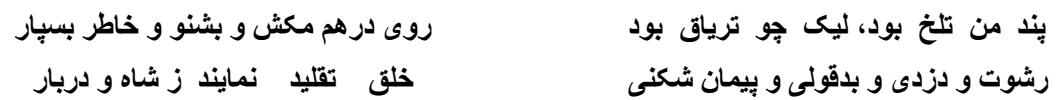

(Bahār, Dìvān, 1: 444).

My word of advice will sound bitter, yet it is as effective as an antidote,

Do not frown, listen, and keep in mind-

Bribery, corruption, insincerity, and disloyalty,

Are improper deeds from which the nation will learn and follow their king and the court.

Hạfiz
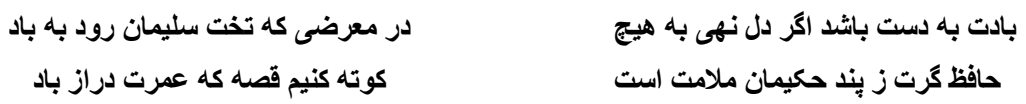

(Hāfiz, Dìvān 1362/1984, 1: g 96, v. 4, 5). 
If you fall in love with worldly property, you will have nothing to show,

Under this firmament, even the throne of Solomon dissolves in the wind.

Hâfiz, if you view the advice of the wise as reproach,

Let us cut the story short and "wish you a long life!"

The following verse was composed by Bahār while imprisoned by Riḍā Shāh. He calls to the Shāh to give him some credit as well as all the blame. Hạfiz utters words similar in meaning but with a much broader radiance.

Bahār

$$
\text { كر كنه بِيدا بود، خدمت جرا بِنهان بود؟ }
$$

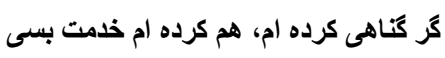

(Bahār, Dīvān, 1: 467).

If I have committed a sin, I have also done good,

If the sin is so apparent, why then is the good concealed?

Hāfiz

$$
\text { نفى حكمت مكن از بهز دل عامى جند }
$$

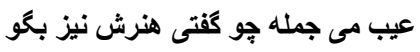

(Hāfiz, Dìvān 1362/1984, 1: g 177, v. 6).

Since all the defects of wine you have declaimed, tell of its virtue as well;

Deny not wisdom in order to please a few.

Bahār's poetry followed Hāfiz's style in meaning and philosophy, but in a way that is somewhat simpler and easier to grasp. With much less ambiguity, Bahār emphasizes his view in the following verse:

Bahār

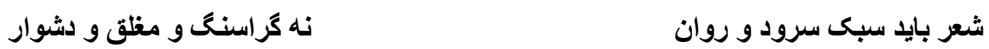

(Bahār, Dīvān, 1: 265).

One must compose poetry that is simple and light,

Not abstruse and hard to grasp.

When we study Bahār's collections of poems, it becomes clear that his poetry has an elegance of its own. In some aspects, especially meaning and rhyme, Hāfiz̧'s influence is apparent, but only a small percentage of Bahār's poetry was directly inspired by Ḥāfiz. The following pair of examples show one instance where Bahār's debt to Ḥâfiz is obvious:

Bahār

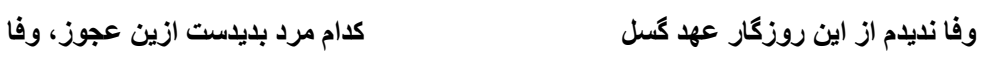

(Bahār, Dìvān, 1: 151).

I have not seen any fidelity from this world.

What man has seen fidelity from this old hag?

Ḥāfiz
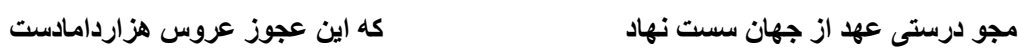

(Hāfiz, Dìvān 1362/1984, 1: g 37, v. 7).

Seek no allegiance from this insecure world.

This old hag is the bride of a thousand bridegrooms. 
In the following verse, Bahār follows Hāfiz to some degree in denotation and concepts. There are also some parallels in rhyme and meter, as in the tadminn (insertion of another poet's hemistich into one's own poem):

Bahār

\section{هزار نكتة باريكتر ز مو اينجاست}

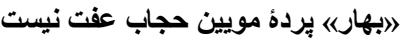

(Rastigār, Muntakhab-i shi'r-i Bahār, 52).

"Bahār," the hair-like veil bears no honor!

Here are a thousand points finer than a hair string.

Hạfiz

$$
\text { هزار نكته باريكتر ز مو اينجاست }
$$

(Hāfiz, Dìvān 1320/1941, g 177, v. 7).

Here are a thousand points finer than a hair:

Not everyone who shaves his head becomes a nomadic dervish.

Bahār

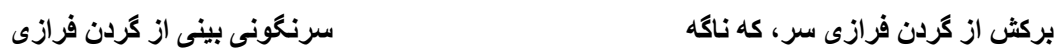

(Bahār, Dīvān, 1: 86).

Do not pursue arrogance, for sudden

Destruction arrives from it!

Hāfiz

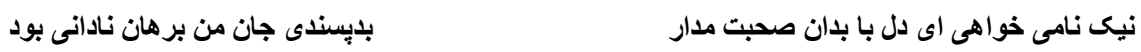

(Hāāiz, Dìvān 1362/1984, 1: g 22, v. 7).

O heart, to seek a good name, beware the companionship of the wicked.

Approval of malevolent ways, my dear, is proof of ignorance.

Bahār

$$
\text { كآفرين شهريار از من بكرداند بلا }
$$

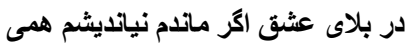

(Bahār, Dīvān, 1: 221).

If hopeless in a love affair, I shall not worry,

For the Lord shall be my protector.

Ḥāfiz

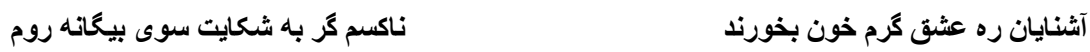

(Ḥāfiz, Dìvān 1362/1984, 1: g 352, v. 4).

Were those acquainted with the trail of love to slay my soul,

I'd be a despicable person if complaining I approached the stranger.

Bahār

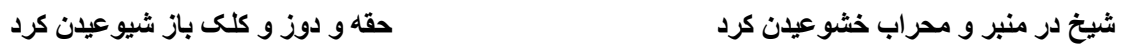

(Bahār, Dìvān, 1: 241).

On the pulpit and in the adytum once again, the clergy began to preach,

The deceit and guileful acts once again began to spread. 
(Hāāiz, Dīvān 1362/1984, 1: g 129, v. 1).

The Sufi laid a snare and began to play tricks-

He laid the basis of deceit against the cunning sky!

Here, Bahār complains about the unsatisfactory situation, but he attempts to match Hāfiz's irony. As the literati were held in low regard during his time, he composes the following satirical poem. The verses follow Hāfiz’s poetry in rhyme, but not in meaning. The underlined words indicate similarities of rhyme.

Bahār

$$
\text { عاقل واقعى آن است كه ماليى دارد }
$$

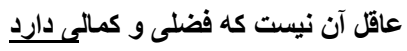

(Bahār, Dīvān, 1: 314).

He who possesses knowledge and wisdom is no sage.

The true sage is he who has wealth and fortune.

Ḥāfiz

$$
\text { بنده طلعت او باش كه آنحى دارد }
$$

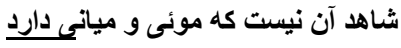

(Ḥāfiz, Dìvān 1362/1984, 1: g 121, v. 1).

A beloved is not defined by beauty and allure:

Be bonded to the countenance of he who has that special persona.

Bahār

$$
\text { آدمى شو اكرت عقل عقالمى دارد }
$$

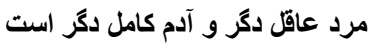

(Bahār, Dìvān, 1: 315).

A wise man differs from a perfect human,

You can become a human if your intellect is compelled by wisdom.

Ḥāíz

$$
\text { هر كسى بر حسب فهم كمانحى دارد }
$$

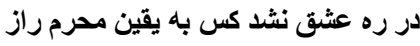

(Hâfiz, Dìvān 1362/1984, 1: g 121, v. 7).

On the path of love, no one has become a true confidant to the mystery:

Everyone's vision measures according to their own understanding.

Bahār

$$
\text { بر خر خود سوار مي بينمٍ }
$$

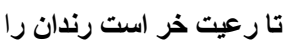

(Bahār, Dìvān, 1: 386).

For as long as the peasants are asses,

I foresee the devious on horseback!

Ḥāfiz

$$
\text { طوق زرين همه بر كردن خر مي بينّ }
$$$$
\text { اسب تازى شده مجروح به زير بالان }
$$

(Although the above verse is widely believed to have been composed by Ḥăfiz, it is recorded in neither Khānlarī’s nor Qazvīnī and Ghanī's edited versions of the Divvān. I am thus doubtful of its composition by the poet).

The Arabian stallion has become feeble under the packsaddle,

Yet I see golden rings around asses' necks!

Bahār

$$
\text { كس از مردم مردم آزارنيست }
$$


There is no act more sinful in the world than setting to vex others.

Ḥāfiz
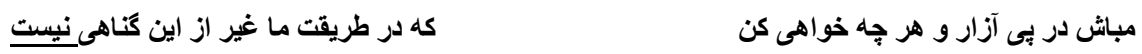

(Hâfiz, Dìvān 1362/1984, 1: g 76, v. 7).

Do not set to vex others and do as you please,

For, in our order, there is no greater sin other than this.

Bahār
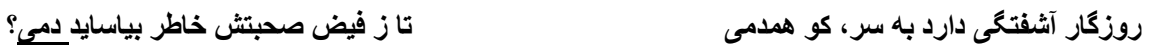

(Bahār, Dīvān, 2: 685).

The world has worrisome plans in mind, where is a companion

Whose grace of utterance can comfort the mind and soul?

Ḥāfiz

$$
\text { دل ز تتهايى به جان آمد خدارا همدمي }
$$

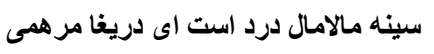

(Ḥāfiz, Dìvān 1362/1984, 2: g 461, v. 1).

The bosom is filled to the brim with pain. Alas for a calming liniment!

Because of loneliness, the heart's at the end of its tether. For God's sake, a companion!

Bahār's discussion of the principles of neoclassical poetry appears in a two-volume anthology of his works titled Bahär va adab-i Fārsī. In it, while speaking about the Indian style during the Safavid period, Bahār emphasizes that many poets of the post-Safavid period emulated the old masters of poetry, such as Rumi, Sa dī, and Hāfiz (Gulbun 1:54-55). Bahār acknowledged Hāfiz as a master poet whose unique and preeminent style has had a profound impact on the general public of Iran as well as on scholars and specialists. Bahār refers to him as a genius, a miracle in the world of poetry, and adds that Hāfiz was a mystic and a spiritual man (Gulbun 1:158). Bahār was a political activist who could have enjoyed a comfortable life and a prestigious position; instead he chose a humble life, in keeping with his ethical beliefs (Āryānpūr 2:328). The following verse clearly indicates his financial standing and the standards by which he lived:

Bahār

$$
\text { از يس مرى عجب جاه و جلالى دارد. }
$$

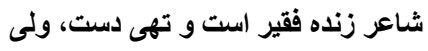

(Bahār, Dīvān, 1: 315).

The poet, while alive, remains poor and needy; but

Wonderful grandeur and glory awaits him after he's gone!

According to Rastigār, another contemporary Iranian scholar, Bahār spent the better part of his life defending his people against tyranny and hypocrisy; many examples of his love of freedom and disapproval of prejudice appear in his poetry (Rastigār, 14). This conduct brings to mind Hāfiz's philosophy, which Bahār had admired from the age of fifteen. Bahār sincerely believed that he was one of the best poets Iran had witnessed since Hâfiz and Sa dī, as he states in the following verse:

Bahār
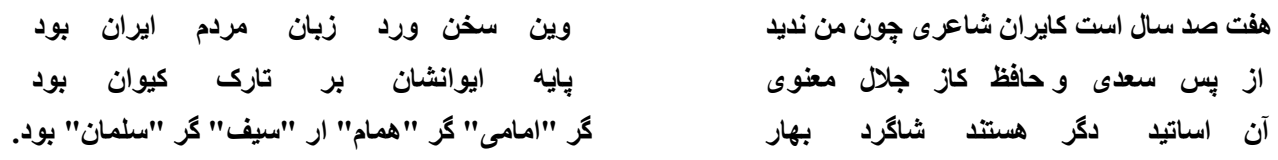

(Bahār, Dìvān, 1: 468).

It has been seven hundred years since Iran witnessed a poet like me.

This statement will be chanted by the people of Iran. 
Since $\mathrm{Sa}^{\mathrm{e}} \mathrm{d} \overline{\mathrm{l}}$ and Hāfiz, whose spiritual glory

Places their very foundation in the heavens,

The other masters, such as "Imāmī," "Humām," "Sayf," or "Salmān,"

Are all students of Bahār.

\section{Conclusion}

One finds originality and novelty in Bahār's work, the beauty of his language is also remarkable. It is probably because his poetry is somewhat influenced by Hāfiz's thought and philosophy. The poets and philosophers since the declining era of the Indian style of poetry emerging during the $15^{\text {th }}$ Century, who remained in Persia and flourished there, writers like Șā'ib, Fighānī, and Jāmī, owed much of their success to Ḥāfiz. For Ḥāfiz had set such high standards in Persian poetry, especially for the ghazal, that anyone who came close to meeting these standards inevitably became illustrious. As we have seen, Bahār pursued Ḥāfiz̧'s example to such an extent that anyone familiar with Hāfiz's poetry could realize his influence on Bahār's writing. This paper aims to demonstrate that most poets who achieved renown after Hāfiz took inspiration from him.

\section{Refrences}

Aḥmad, N. (Summer 1367/1988). Naẓarī dar Dīvān-i Ḥāfiz. Iran Nameh, 2(1), 126-40.

Anvari, H. (1381/2002). Farhang-i buzurg-i sukhan. Tehran: Sukhan.

Arberry, A. J. (1958). Classical Persian Literature. London: George Allen \& Unwin.

Āryānpūr, Y. (1372/1952). Az șabā tā nimā: tārikh-i 150 sāl adab-i fārsī (Vol. 2). Tehran: Zavvār.

Āshtīyānī, S. J. (1377/1998). shi'r va andisha. Tehran: nashr-i markaz.

Āshūrī, D. (1382/2003). 'irfān va rindī dar shi 'r-i Hāfiz. Tehran: nashr-i markaz.

Avery, P. (2010). Hāāiz of Shīrāz. In L. Lewisohn, \& L. Lewisohn (Ed.), Hafiz and the Religion of Love in Classical Persian Poetry. London: I. B. Tauris.

'Arif. (1381/2002). D̄̄vān-i 'Ārif Qazvīnī. (Sipanlu, Ed.) Tehran: Nigāh.

Bahār. (1944). Tārikh-i mukhtaṣar-i aḥzāb-i sīyāsī: Inqirạ̣̄-i salțanat-i Qājārīya. Tehran: Nigāh.

—. (1380/2001). Dìvān-i 'ash'ār. (C. Bahar, Ed.) Tehran: Intishārāt-i Ṭūs.

Bell, G. L. 1937. The Earlier Letters. (E. Richmond, Ed.) New York: Liveright.

- 2003. The Garden of Heaven: Poems of Hafiz. Mineola, NY: Dover.

Bely, A. (1980). The magic of words. t.G.West, Symbolyism: An anthology, 127.

Bly, R. a. (2008). The Angels Knocking on the Tavern Door:Thirty Poems of Hafez. (Bly, R., and L. Lewisohn, Trans.) New York: Harper Collins.

Bosnavī, M. S. (1374/1966). sharḥ-i Sūd̄̄ bar Hāafiz (Vol. 4). ( . Sattārzāda, Trans.) Tehran: zarrīn.

Browne, E. G. (1906-20). Reprinted Bethesda, MD: Iranbook, 1997). A Literary History of Persia. Cambridge: Cambridge University Press.

- (1920). A History of Persian Literature under Tatar Dominion (A.D. 1265-1502). Cambridge: Cambridge University Press.

Bruijn, J. T. (EI 8 (1980): 531). Rind. Retrieved October 25, 2013, from Encyclopedia of Islam.

-. (XI/5 (2002): 469-474). Hafez iii. Hafez's Poetic Art. Retrieved October 25, 2013, from Encyclopaedia Iranica: www.iranicaonline.org/articles/hafez-iii

Burgel, C. (1988). The Romance In Persian Literature. In E. Yarshater (Ed.), Bibliotheca Persica Lectures on Iranian Studies 3 (p. 161). New York: Persian Heritage Foundation.

Dārābī, M. (1357/1979). Lațifa ghaybī: Hāâiz Shīrāzì bi ḍamima-yi bayān-i iṣtilāhāt-i ahl-i ‘irfān. Shīrāz: kitāb-khānayi Aḥmadī.

Dashtī. (1381/2002). naqshī az Hāfiz. Tehran: Amīr Kabīr.

—. (1385/2007). kākh-i ibdā'. Tehran: shirkat-i qalam.

Davis, D. (2012). Faces of Love: Hafez and the Poets of Shiraz. Washington D.C.: Mage.

Dhu'l-Nūr, R. (1362/1984). dar justujū-yi Hāfiz. (R. Dhu'l-Nūr, Ed.) Tehran: zavvār.

Dihkhudā, `. A. (1336/1958). lughat-nāma: muqadama. Tehran: Tehran University Press.

—. (1352/1974). Amthāl va hikam. Tehran: Sipihr.

—. (1381/2002). charand u parand. Tehran: Afrāsīyāb.

Elliot, R. C. (1982). The Literary Persona. Chicago: University of Chicago Press. 
Frye, R. N. (2011). Persia. 5(Routledge Library Edition: Iran). London: Routledge Taylor \& Francis.

Ghanī, Q. (1322/1944). baḥth dar āthār va afkār va aḥvāl-i Hāfiz: tārīkh-i aṣr-i Hāấz yā tārikh-i fārs va muḍāfāt va ayālāt-i mujāvirī dar qarn-i hashtum. Tehran: zavvār.

Glasse, C. (2001). The New Encyclopedia of Islam. Walnut Creek, CA: Alta Mira.

Gray, E. T. (2002). Hājiz the Green Sea of Heaven: Fifty Ghazals from the Dīwān of Hāfiz. (E. T. Gray, Trans.) Ashland, OR: White Cloud.

Gulbun, M. (1351/1972). Bahār va adab-i Fārsī: Majmū ì-yi yikṣad maqāla az Malik al-Shu arā-yi Bahār. Tehran: Kitābhā-yi Jib̄̄.

Ḥāfiz, K. S.-D. (1306/1928). Dīvān-i Khwāja Hūāfiz Shīrāzī: Az rū-yi nuskha-yi khaț̣̄ ki dar tārikh-i 827 Hijrī qamarī 35 sāl ba'd az vafāt-i Khwāja taḥrir shuda ast. (Khalkhālī, Ed.) Tehran: Bunyād-i Kitāb.

—. (1320/1941; 1381/2003). Dīvān-i Khwāja Shams al-Dīn Muhammad Hāâfiz Shīrāzī. (Muhammad Qazvīnī, Qāsim Ghan̄i, Ed.) Tehran: Kitābkhāna Zavvār.

—. (1362/1984). Dīvān-i Khwāja Shams al-Dīn Muhammad: Mulhaqāt-i ghazalīyāt, qașā'id, mathnavīyyāt, qața āt va rubā'ìyāt. (Khānlarī, Ed.) Tehran: Khārazmī.

—. (1366/1988). Dīvān-i kuhna-yi Hāfiz: Az ruy-i nuskha-yi khaț̣īi nazdik bi zamān-i shā'ir. (Ī. Afshār, Ed.) Tehran: Amīr Kabīr.

—. (1378/1999). Dīvān-i Hāâfiz. (B. Khurramshāhī, H. Jāvīd, Ed.) Tehran: Farzān.

Isti lāmī, M. (54th series, year 11, Shāhanshāhī 2535, 1355/1976). darvish-i bi rang. Talāsh (11), pp. 42-45.

—. Spring (1386/2007). shamāyil-i ma`shūq dar kalām-i Ḥāfiz. Iran Shināsī 19 (1), 25-32.

Ivanow, W. (1926). Biblitheca Indica: A Collection of Oriental Works: Concise Descriptive Catalogue of Persian Manuscripts in the Curzon Collection Asiatic Society of Bengal. Calcutta: Baptism Mission Press.

Kadkan̄̄, M. S. (1350/1971). șuvar-i khīyāl dar shi'r-i fārsī: tahqū̄q-i intiqādī dar taț̣avūr-i ìmāzhhā-yi shi'r-i pārsī va sayr-i nazarīya-yi balāghat dar Islam va Iran. Tehran: āgāh.

-. (1380/2002). advār-i shi'r-i fārsī. Tehran: sukhan.

-. (1381/2002). mūsiqū-i shi'r. Tehran: āgāh.

—. (1385/2006). in kīmiyāa-yi hastī. (V. A. Durūdīyān, Ed.) Tehran: intishārāt-i āyīn.

Khāliqī, M. B. (1382/2004). shākh-i nabāt: sharhh-i ghazalhāa. Tehran: zavvār.

Khalkhālī, S. 'A. (1331/1953). tadhkira-yi shu'arā-yi mu'āṣir-i Iran. Tehran: Ṭahūrī.

Khānlarī, P. N. (1332/1957). sukhan: adabīyāt-i muēạsir-i Iran. Majala-i adabīyāt va dānish va hunar-i imrūz (6), 637.

Khorramshāhi, B. (2002: 465-69). Hafez ii. Hafez's Life and Time. Retrieved October 11, 2011, from Encyclopaedia Iranica, XI/5: www.iranicaonline.org/articles/hafez-ii.

-. (2002: 497-83). Hāfez vi. Printed Editions of the Divān of Hafez. Retrieved November 09, 2011, from Encyclopedia Iranica XI/5: www.iranicaonline.org/articles/hafez-vi.

—. (1366/1987). Hāfiž-nāma: sharh-i alfāz, a lām, mafāhim-i kilid̄̄ va abyāt-i dushvār-i Hāafiz. Tehran: intishārāt-i surūsh.

—. (1367/1988). dhihn u zabān-i Hāafiz. Tehran: intishārāt-i khas.

—. (1387/2008). Hāfiz. Tehran: Nāhid.

—. (Summer 1373/1995). bi munāsibat-i taṣhịị̄ az dīvān-i Ḥāfiz. māh-nāma yi Kilk(53), 50-53.

—. (Summer 1988). mayl-i Ḥāfiz bi gunāh. Iran Nameh 6(4), 662-95.

—. (1385/2006). Ḥāfiz dar farhang-i mā va farhang-i mā dar Ḥāfiz. In Hââfiz hậfizaa-yi māst. Tehran: Intishārāt-i nashr-i Qațra.

Kirmānī, S. N. (1364/1986). Ḥāfiz az dīdgāhhā-yi mukhtalif. Tehran: ādhar ābādigān.

—. (1376/1997). Hāâfiz shināsī. Tehran: intishārāt-i pazhang.

Kutbī, M. (1374/1996). sharḥ-i 'irfānī-i ghazalhā-yi Hāafiz. (K. M. B. Khorramshāhi, Ed.) Tehran: qațra.

Lāhūrī. (1378/1999). Sharḥ-i 'irfānī-yi ghazalhā-yi Hāafez. (B. Khorramshāhi, Ed.) Tehran: Qaṭra.

Leaf, W. (1898). Versions from Hāfiz: An Essay in Persian Metre. London: Grant Richards.

Levy, R. (1969). An Introduction to Persian Literature. New York: Columbia University Press.

Lewis, F. (2002: 483-91). Hafez viii. Hafez and Rendi. Retrieved September 20, 2012, from Encyclopaedia Iranica, $\mathrm{XI} / 5$ : www.iranicaonline.org/articles/hafez-viii.

Lewisohn, L. (1995). Beyond Faith and Infidelity: The Sufi Poetry and Teachings of Mahmud Shabistari. Richmond, UK: Curzon.

-. (2010). Prolegomenon. In Hāfiz and the Religion of Love. London: I. B. Tauris. 
-. (2012). Hafiz and the religion of love in classical Persian poetry. London, UK: I.B. Tauris.

—. (part 3, 1998). An Introduction to the History of Modern Persian Sufism, Part I: The Niemat-Ullāhī Order: Persecution, Revival and Schism. Bulletin of the School of Oriental \& African Studies 61.

Loraine, M. B. (476-479). Bahār, Malek al Šo 'arā', i. Life and Work'. Retrieved from Elr III.

Losensky, P. E. (1998 [122]). Welcoming Fighānī: Imitation and Poetic Individuality in the Safavīd-Mughal Ghazal. Costa Mesa, CA: Mazda.

Maḥjūb, M. J. (1363/1985). sabk-i khurāsān̄̄ dar shi'r-i fārsī: bar rasī-i mukhtașṣāt-i shi' r-i fārsī, az āghāz-i ẓuhūr tā pāyān-i qarn-i panjum-i hijri. Tehran: Firdawsī.

Meisami, J. S. (2002: 476-79). Hafez v. Manuscripts of Hafez . Retrieved June 04, 2012, from Encyclopaedia Iranica, $\mathrm{XI} / 5$ : www.iranicaonline.org/articles/hafez-v.

Melville, C. (1998). History and Literature in Iran. Cambridge: Cambridge University Press.

Meskūb, S. (1992). Iranian Nationality and the Persian Language. Washington, DC: Mage.

Mu'īn, M. (1373/1994). Farhang-i Mu'īn. Tehran: Amīr Kabīr.

Nash, G. (2005). From Empire to Orient, Travellers to the Middle East, 18301926 . London: I. B. Tauris.

Nāzir, M. (1360/1981). Nigārish bar ash'ār-i Parvin-i I'tișāmī: Some Observations on the Poetry of Parvin I'tișāmī. Tehran: Surūsh.

Nudūshan, M. (Summer 1988). shīva-yi shāe irī-yi Ḥāfiz. Iran Nameh 6(4), 521-58.

Parsinejad, İ. (1382/2003). A History of Literary Criticism in Iran, 1866-1915. Bethesda, MD: Ibex.

Rastigār, G. F. (1351/1973). Muntakhab-i shi 'r-i Bahār va barrisi-i kūtāh̄̄ az ash ‘ār-i aū. Tehran: Bāstān.

Shamīsā, S. (1381/2002). Shāhid bāzī dar adabiyyāt-i Fārsī. Tehran: Firdaws.

—. (1383/2005). naqd-i adabī. Tehran: Firdawsī.

Schimmel, A. (1992). A Two-Colored Brocade: The Imagery of Persian Poetry. Chapel Hill: North Carolina University Press.

Solati, B. (2013). The reception of Hafiz: The Sweet Poetic Language of Hāfiz in Ninteenth and Twentieth Century Persia. Leiden, the Netherlands: Leiden University Press.

Subhā̄n̄̄, H. (1386/2007). tārikh-i adabīyāt-i Iran. Tehran: zavvar.

Talattof, K. (2000). The Politics of Writing in Iran: A History of Modern Persian Literature. Syracuse, NY: Syracuse University Press.

Thackston, W. M. (1994). A Millennium of Classical Persian Poetry: A Guid to the Reading \& Understanding of Persian Poetry from the Tenth to the Twentieth Century. Bethesda, Maryland: IranBooks.

Wellek, R. a. (2002). Hāfiẓ’s Life and Times. In Encyclopedia Iranica 11 (p. 465).

—. (1977). Theory of Literature. New York: Harcourt Brace Janovich.

Yarshater, E. (1988). Persian Literature. In E. Yarshater (Ed.), Columbia Lectures on Iranian Studies 3. New York: Bibliotheca Persica/Persian Heritage Foundation.

Zarrinkūb, ‘. H.. (1349/1971). az kūcha-yi rindān. Tehran: kitābhā-i jibī.

—. (1363/1984). sayrī dar shi' r-i fārsī. Tehran: intishārāt-i Nuvīn. 